\title{
Research on the construction of E-commerce Platform for Agricultural Products in Jilin Province
}

\author{
Chunrong Zhang \\ Changchun Guanghua University,Changchun, China \\ 523444470@qq.com
}

\begin{abstract}
Keywords: Jilin province; Agricultural e-commerce platform; Construction; Application; Case analysis
\end{abstract}

\begin{abstract}
Due to the rapid development of agricultural informatization and agricultural industrialization, computer technology and network technology has become an indispensable part in agricultural modernization, and the technology of computer and Internet technology to promote e-commerce development is exerted an important influence on agricultural products, e-commerce provides new opportunities with characteristics their high efficiency low cost and without the limit of time and space for the rural economy promotion. This article from the development situation of foreign agricultural products e-commerce and the existing mode, China introduced the development of e-commerce of agricultural products and agricultural products in Jilin Province, according to the demand of e-commerce platform construction, poly agriculture e purchase "and" post agricultural products "2 based on the characteristics of Jilin agricultural products e-commerce platform an example is analyzed in detail, in order to Jilin agricultural products trade in transition and development in the new period of reference.
\end{abstract}

\section{Introduction}

With the gradual updating and replacement of information technology, the traditional business model has gradually changed to the modern electronic commerce model. The entry of agricultural products into the era of e-business marketing is an inevitable trend, and it is also a revolutionary change in the circulation of agricultural products. In twentieth Century, when the telephone became the mainstream communication tool, the primary e-commerce came into being. After entering the Internet era, online transactions increased day by day. After twenty-first Century, GPS technology was introduced into the network business applications, making online transactions more convenient. China is a large agricultural production country, which has formed its traditional agricultural trade system for many years. The traditional trade mode, the production of agricultural products and circulation by producers (farmers) primary wholesale market - sales wholesale markets, farmers market or supermarket, consumers and other aspects, which includes a number of intermediaries, the circulation of low efficiency and high cost [1-2]. With the development of e-commerce, the production and circulation of agricultural products gradually change to low cost and high efficiency direction, and gradually affect people's life style and ideas. Based on the summary of the development of agricultural e-commerce at home and abroad, combined with the needs of the construction of Jilin regional agricultural e-commerce platform, we make an empirical analysis, in order to promote the development and transformation of Jilin's agricultural products trade.

\section{The Development of e-commerce of Agricultural Products}

The Development Situation of Foreign Agricultural Products e-commerce. The United States is the first country to carry out the electronic commerce of agricultural products, which is inseparable from its highly developed information level and Internet technology. Conform to the production and consumption of agricultural products chain, the e-commerce of agricultural products to extend to the ends of end: production for farmers, farms, the agricultural products through the network or internet 
order; the consumer side is more diversified, including large trade of agricultural products and agricultural products business enterprise website system. The futures trading of agricultural products derived from agricultural products has also developed gradually, making the change of market market easier to obtain [3].

Britain is also one of the countries with high degree of electronic commerce in agricultural products. From Farming Online to agricultural service website construction, then generate more electricity supplier website; and almost $90 \%$ of the farm access site provides the production of agricultural products and agricultural products, the government provides a special gateway for farmers (more than $70 \%$ of the login account), agricultural enterprises through its participation in management; create a lot of agricultural website its own brand, welcomed by consumers.

In recent years, the electronic commerce of agricultural products in Japan has developed rapidly. The government has introduced and implemented the relevant standards to promote the construction of agricultural products. The online supermarket, the network trade market, the auction trading platform for agricultural products and the electronic exchange of agricultural products have been gradually formed. In addition, the different functions of the website to provide related services, such as foreign agricultural information website, is conducive to the development of international trade of agricultural products; agricultural technology information network system can provide services and systems in the pest control rule; the user can develop training system to provide support and technical training.

Basic Models of China's Agricultural Products e-commerce. With the gradual implementation of the agricultural product market system construction plan, under the government support, China has basically established a modern circulation system of agricultural market open, competitive and orderly, which covers electronic business, modern logistics, distribution chain, futures market and other aspects of [4]. Especially in recent years, the electronic commerce of agricultural products in China has developed rapidly and the system is becoming more and more perfect. Beijing, Shenzhen, Chengdu, Changsha and other cities have the same city farm products e-commerce platform. According to statistics, at present, the electronic commerce platform of agricultural products has reached 3000 , and it has already entered the era of contending for a hundred families. At present, the electronic commerce of agricultural products in our country can be summed up as the following basic models.

B2B (merchant to merchant) mode. Agricultural products production, processing, sales and service business transactions between the use of e-commerce technology, including online trading, information intermediary, futures market, the main service object is the enterprise of supply and demand of agricultural products, including agricultural products circulation in the process of [5] manufacturers and distributors.

B2C (merchant to customer) mode. The supply of agricultural products enterprises or producers of agricultural products to establish a network platform of agricultural products, including various forms of information publicity, shop website, online ordering system, provide sales and service, while reducing the intermediate links, but due to the limited knowledge of farmers and rural infrastructure, agricultural products in e-commerce transactions is not high proportion of [6].

C2C (customer to customer) mode. The e-business model is mainly used to deal with farmers, agricultural cooperatives and individual consumers. It has many applications in special agricultural products and local fresh food supply and marketing, so as to provide convenience for consumers to purchase agricultural products from farmers directly, so as to adapt to the decentralized production status of agricultural products in China.

G2C (government to customer) model. The government provides information for agricultural production, processing and sales enterprises through agricultural websites, promoting information circulation, and realizing the functions of public service and guidance in the government.

Third party e-commerce model. The third party business platform provides professional commodity display, marketing, online transaction, information data and other platforms, which supply services for both sides, promoting fair competition, saving the cost of agricultural products supply enterprises, and protecting the interests of consumers.

Electronic auction model of agricultural products. Auction intermediary is commissioned by agricultural products suppliers, providing a platform for public bidding of agricultural products, 
including 2 aspects, electronic auction and bidding. Targeted and regionally strong, it helps reduce transaction costs and risks.

\section{Development Status of Electronic Commerce Platform for Agricultural Products in JILIN}

In recent years, Jilin province to actively support the development of e-commerce, developed a lot of e-commerce development planning, purchase facilities, accelerate development, to build the first regional e-commerce platform and the China Electronic Commerce Center, Jilin international e-commerce platform. It is a public information platform for the export of agricultural products, which plays an important role in the development of agricultural products in Jilin province.

As of 2014, the e-commerce application platform developed 18523 members, covering most of the foreign trade enterprises. At the same time, it strengthened cooperation with relevant parties in Heilongjiang, and maintained good advantages in communication, and achieved good results. And with the increasing number of agricultural products trade in Jilin Province, Jilin province has transformed the original agricultural product wholesale market into two provincial agricultural products trading and logistics centers, so that Jilin's agricultural products can be purchased by ordinary consumers. With the rapid development of the market for agricultural products and the improvement of the related infrastructure, it will provide a better channel for the sales of other parts of the agricultural products.

\section{Problems in the Development of Electronic Commerce Platform for Agricultural Products in Jilin Province}

Deficiencies in the Standardization of Information Facilities. At present, the construction of digital city in Jilin province is advancing steadily in enterprise informatization, e-government and social informatization. At the same time, it has achieved positive results and provided new impetus for Jilin's economic development. Despite the development of its information facilities, the lack of comprehensive information services and commercial services related to agricultural trade in Jilin province greatly restricts the development of agricultural e-commerce in Jilin province. More important is its packaging and quality and product coding due to regional differences in agricultural products, which hindered the standardization of agricultural products in Jilin Province.

Inadequate Agricultural Information Classification Standards. At present, the agricultural websites in Jilin province and HEILONGJIANG province lack professional standards, the updating cycle is long, from the form to the content have a lot of common ground, such as the payment function is not perfect, part of the website set up functions. For example, in the case of the fruit produce network of the service organization that provides the fruit distribution information platform in Jilin province, the website mainly focuses on the supply and demand information and does not have the complete business operation function.

Weak Farmers 'Access to Information. At present, the main factors affecting rural Internet access are poor network infrastructure construction, low network utilization and high cost of use. By December 2014, the rural mobile phone penetration rate in Jilin Province had reached 82.98 percent, and the village broadband penetration rate approved by provincial and municipal authorities reached 93.4 percent. Data also show that rural netizens in Jilin Province rely more on mobile phone terminals, rural New netizens use mobile phone access as high as $75.2 \%$. It can be seen that, although Jilin has made great achievements, but the above data, compared with advanced provinces and cities, there is still a distance, mainly the ministry of agriculture related to the integration and sharing of information resources. Restricted by economic and cultural level, farmers are not able to obtain information from the Internet in a timely and direct manner and lack the ability to analyze and select the information they obtain. 


\section{A Case Study on Construction of Electronic Commerce Platform for Agricultural Products in Jilin Province}

"Peasant E Buy" Agricultural Electronics Mall. Faced with the new production and management of the specialized and personalized demand, Jilin province rural integrated economic information center(Jilin farmer network for short), based on the public good "three farmers" information service, actively explore a new way to market operation, built and operated "farming E purchase" agricultural products electronic mall. "Polynong E" electric trading platform is positioned as a non-profit platform, to help traditional enterprises quickly online, mainly engaged in Jilin Province famous excellent agricultural products, including mountain products, specialty food, tea, grain and oil products, livestock and aquatic products, seedlings and flowers, six categories of Jilin named excellent agricultural products, and will gradually expand agricultural capital, agricultural machinery and other agricultural products.

The existing foundation. First, the advantages of the organization system. Jilin rural network has established five level service system of province, city, county, township and village, and has established good partnership with relevant departments, such as agriculture related departments, universities and institutes of science, with certain social influence and credibility. The two is the large amount of information resources. The agricultural information related resources of Jilin agricultural network covers all aspects of agricultural production, agricultural product management and rural social management. The three is the wide coverage of the means of service. The service mode includes short color letter, terminal product, expert service, voice service, telephone, mobile phone client and so on. Four is the technical advantages of the platform. After years of construction, we have formed an application service platform represented by the rural comprehensive service platform, the demonstration province platform and the Agricultural Internet of things platform, with relatively fixed user groups.

Platform construction measures. Poly agriculture e purchase is in the Provincial Meteorological Bureau, the provincial Agriculture Commission, the provincial Commission by letter, the provincial commerce department, the provincial science and Technology Department, provincial propaganda office, provincial Party Committee Organization Department and other departments to support the construction of audio-visual center under the line, from the rural comprehensive information center of Jilin province and Jilin agricultural information network technology services limited the market operation, the construction of professional business team. Based on the technical advantages of agricultural network, a series of localization and individualized design of the electronic commerce platform for agricultural products has been carried out. To determine the service of agricultural enterprises in Jilin, for the customers "service concept, mainly engaged in famous agricultural products in Jilin Province, to help enterprises zero cost through sales and promotion.

Construction effect. "Poly farm e purchase " in April 28, 2016 on-line operations since, has settled more than 100 enterprises, more than 2500 commodity merchants settled products covers 6 categories, 35 small classes, covering most of the characteristics of Jilin agricultural products, the enterprises are well-known agricultural enterprises in Jilin Province, product quality preference. At present, "farm e purchase" daily average browsing volume is more than 5000, as of June 30th, to achieve more than 360 orders, customers from all over the country. In addition, the promotion means of early "poly e purchase" is mainly based on the Jilin rural network's own channels, and the existing coverage means of the Department has been used to achieve the full coverage of the platform's publicity and promotion. Publicity and promotion in the electronic display, rural information platform, the TV weather forecast, the official website, micro-blog, WeChat, client, agent hosted website; to carry out strategic cooperation with Jilin first online community -- Hefei forum, conducted online and offline promotion activities; the use of China agriculture net, net, my brother provinces Rural Valley other business units to carry out the "junong e purchase electronic business platform of promotional activities.

Agricultural e-commerce Platform "Post Agricultural Products". "Post agricultural products" is to create a joint government Chinese Post Group Corporation of Jilin province and the country's largest agricultural e-commerce base in agricultural products manufacturers (B) (B), rural cooperatives, agricultural products processing enterprises (B), agricultural product trade enterprises (B) and consumer (C). Exchange, interaction, to achieve online transactions, product traceability, logistics tracking, 
information release, Jilin province has gradually become the most important quality agricultural products exhibition, promotion of e-commerce platform.

Organization system. One is the main body of investment and operation. "Post agricultural products" is the main investment operations in the post (Jilin) network technology limited company (owned by China postal group). The two is the main body of service. The main service post agricultural products "is the agricultural product producers (farmers), rural cooperatives, agricultural products processing enterprises, agricultural products trade enterprises and consumers. The three is the operation mode. (1) B2B supply chain operation. The electronic commerce platform is provided for farmers, rural cooperatives and enterprises to purchase and sell products, purchase raw materials and purchase agricultural capital. B2C sales chain operation. "Post agricultural products" from the China post successful operation of online shopping mall - ule operating experience, e-commerce platform for agricultural products, promote agricultural products enterprise transformation from the traditional marketing for enterprise e-commerce and traditional marketing combination of modern enterprise.

Institutions. First, the construction and gradual improvement of the platform. The basic function of post agricultural product "module: enterprise registration management; online shops; multifunctional online video hall; transactions, payment and settlement and logistics support. The two is to develop online B2B transactions. The platform carries out the accurate propaganda, chooses some enterprises to carry out online trading first, and then vigorously develop the investment, and gradually promote to other enterprises. Three is the timely entry into the B2C field. The products produced by the member enterprises are sold on the platform to the end consumers. The first phase mainly provides the website transaction, and then gradually covers the mobile terminal, the call center and other channels. In order to provide the rural market with high price, good quality and guaranteed quality, agricultural machinery, daily chemical and other consumer goods. Four is the initial realization of commodity circulation information tracking and product information traceability. "Post agricultural products" platform provides a unified interface specification, and cooperation of logistics enterprises to realize network, providing real-time information flow tracking and product information query. The six is that the offline sales channels are basically built. We should establish a complete and complete underline entity shop, promote the super sales of commodity entry merchants and strengthen the cooperation of commodity marketing.

Construction results. One is information interaction. "Provides an intermediary platform of agricultural products, farmers mail" brokered transactions; provides a reservation platform to provide online bidding, advance online ordering transactions, the manufacturers and dealers do production orders; processors can participate, understand the production process, by providing financial support to reduce the cost of purchase. Through two-way recommendation, it has opened an intelligent communication channel among the members of the enterprise. Two is the online commodity sales. "Post agricultural products" website, call center, mobile phone terminals and other channels, so that the final consumers of agricultural products (individual members) through these channels can easily query and display of goods purchased on the platform, enjoy the whole process of full payment, logistics, customer service and other services. Three is the sale of agent under line. We use the postal network resources which are all over the urban and rural areas, and build a physical store with functions such as display, sale and after-sale service. We will provide platform shopping service by postal outlets and business super. Four is the information tracking of commodity circulation. The platform can be used with the postal service, one of four links and other logistics service enterprises related systems directly connected, using the Internet, telephone, mobile phone text messages and other means, to provide the whole process of logistics information services to manufacturers, distributors, including factory time, logistics enterprises each transit node time, sales time etc.. Five is the product information traceability. It realizes anti-counterfeiting tracing from source of production to consumption terminal, and provides simple and feasible inquiry service of production information, production environment information and production process information of single product. Six is to open up agricultural technology information garden. Combined with the government led "agricultural technology service last mile" project, we set up functions of agricultural technology experts database, online answering questions, online booking and other functions on the platform, and achieve real-time interaction of agricultural technology services 
through websites, mobile clients, customer service hotlines and so on.

\section{Conclusion}

Jilin Province agricultural product diversity, abundant resources, and the construction and development of the electronic commerce platform can provide a more convenient way for the trade of agricultural products, plus Jilin province attaches great importance to the development of agricultural e-commerce platform, has provided great convenience for agricultural products e-commerce platform policy of taiwan.

The localized e-commerce platform should continue to vigorously strengthen the platform construction, form a relatively complete platform system standard, and strengthen the personnel configuration of the e-business team, further improve the main function and improve the user experience effect. We should further publicize and publicize all kinds of forms, such as TV media, Internet media, print media, etc., and continue to take offline activities to increase public credibility, popularity and reputation, thereby increasing traffic and bringing considerable sales to businesses. We should further carry out investment promotion work, strengthen the linkage and linkage with local governments and related industries and associations, and package the characteristic agricultural products enterprises in cities and counties, and set up the famous agricultural products area in cities and counties. Through the building of the core business, we will join the ranks of the mainstream network trade in China's agricultural products and rural consumer goods. In addition, vigorously promote mobile Internet services, to explore, bold innovation, focus on the development of mobile phone client, WeChat $\mathrm{O} 2 \mathrm{O}$ (Online to Offline) mode, to keep pace with the times, gradually formed a three-dimensional, full coverage of the Jilin famous agricultural products business platform. Finally, we should actively cooperate with other countries to attract more resources such as capital, technology and management, so as to lay a solid foundation for developing China's authoritative trade and information platform, improving the international marketing system and realizing the internationalization of capital, technology and market.

\section{References}

[1] Guangzhou Zhao, Yufang Wang, YuJie Lan. China's agricultural products e-commerce development and research status of the [J]. Mode of Modern Agriculture, 2012 (12): 37-39.

[2] Jun Peng , Xiaoying Huang. The consumer safety certification of agricultural products and consumer behavior survey --based on Hangzhou County consumer survey [J]. Agricultural Information in China, 2014 (2).

[3] Jun Ge , Fengxian Yan, Chenglin Yang. The development of e-commerce mode of foreign agricultural products of China from [J]. World Agriculture, 2013 (5): 48-51.

[4] Yanru Jiao.The development mode and Countermeasures of agricultural products e-commerce [J]. Rural economy and Science and Technology, 2014 (3): 82-84.

[5] Jie Zhang . Analysis of e-commerce transaction risk and security technology of [J]. Chinese e-commerce, 2014 (9).

[6] Jiaqiang Sun .Analysis and countermeasure research on the integrity of e-commerce enterprises[J].Enterprise Guide, 2013 (5). 